\title{
Vitamin D: Current status of its role in Periodontal disease
}

\author{
Rajashree Dasari* \\ Panineeya Mahavidyalaya Institute of Dental Sciences and Research centre, India
}

Submission: March 28, 2018; Published: May 23, 2018

*Corresponding author: Rajashree Dasari, Associate professor, Panineeya Mahavidyalaya Institute of Dental Sciences and Research centre, Dilshuknagar, Hyderabad-60, India, Tel: 919866606363/040-65981853; Email: drrajashree21@gmail.com

\begin{abstract}
The risk of developing periodontal disease might be affected by vitamin D deficiency. The effect could be via low bone mineral density or through immunomodulatory effects. Studies show the association between periodontitis, bone metabolism and VDR polymorphisms. 1,25(OH)2D acts as a ligand for the vitamin D receptor (VDR), a transcription factor, helps to bind sites in the DNA called vitamin D response elements (VDREs). These binding sites regulate numerous genes in a cell-specific manner. 1,25(OH)2D analogs with minimal side effects are being developed to target specific diseases with minimal side effects. The interest in impact or role of vitamin $\mathrm{D}$ in various biological processes has been rapidly increased in past several years and evidenced by number of publications with the finding of vitamin D receptor (VDR) and its binding sites in almost every tissue and thereby controlling hundreds of genes. Understanding the detailed mechanisms and role of vitamin D in periodontal disease could open a new therapeutic approach for periodontists and also help in early detection and better outcome of periodontal therapy. This review will examine these different functions of vitamin D, its mechanism of action, and clinical application.
\end{abstract}

Keywords: Vitamin D; Vitamin D Receptor; Periodontal disease.

Abbreviations: VDR: Vitamin D Receptor; VDREs: Vitamin D Response Elements

\section{Introduction}

Vitamin D, in tradition has been associated with bone health and its deficiency leads to rickets in children and osteomalacia/ osteoporosis in adults. [1] However, for optimal functioning of many organs and tissues throughout the body, adequate vitamin D is important. [2] In most of the population including children and young adult's deficiency or insufficiency of Vitamin D is prevalent which generally remains untreated and unrecognized. Although vitamin D is consumed in food, dietary intake alone is often insufficient, supplying only $20 \%$ of the body's requirements.

An emerging hypothesis is that vitamin D may be beneficial for oral health, for its direct effect on bone metabolism and also its ability to function as an anti-inflammatory agent and stimulate the production of anti-microbial peptides. In recent years, the discovery of the vitamin D receptor (VDR) in the cells of the immune system and the fact that several of these cells produce the vitamin D hormone suggested that it could have immunoregulatory properties.

Evidence has demonstrated that deficiency of vitamin D may place subjects at risk for not only low bone density but also many chronic inflammatory diseases including periodontitis. Studies have also shown that low bone mass could be a risk factor for periodontal disease. Thus, to understand the future clinical applications of vitamin D it is important to understand steps of vitamin D metabolism and mechanisms of action that can be altered to facilitate tissue-specific clinical applications.

\section{Discussion}

\section{Vitamin D Metabolism}

Under the influence of UV light, Vitamin D3 is made in the skin from 7-dehydrocholesterol. It is first metabolized to 25 hydroxyvitamin D (250HD), then to the hormonal form 1,25-dihydroxyvitamin $\mathrm{D}\left(1,25(\mathrm{OH})_{2} \mathrm{D}\right)$ by CYP2R1 which is the most important 25-hydroxylase and CYP27B1, the key 1-hydroxylase respectively.

Both $250 \mathrm{HD}$ and $1,25(\mathrm{OH})_{2} \mathrm{D}$ are catabolized by CYP24A1. [3] $1,25(\mathrm{OH})_{2} \mathrm{D}$ acts as a ligand for the Vitamin D Receptor (VDR), a transcription factor, which binds to sites in the DNA called Vitamin D Response Elements (VDREs). There are thousands of these binding sites regulating hundreds of genes in a cell-specific fashion. Analogs of $1,25(\mathrm{OH})_{2} \mathrm{D}$ are being developed to target specific diseases with minimal side effects. This review will examine these different functions of vitamin D metabolism, its mechanism and clinical application. 


\section{Genomic and Non-Genomic Actions of Vitamin D}

Most of the genomic actions of $1,25(\mathrm{OH})_{2} \mathrm{D}$ are mediated by the VDR. VDR is a transcription factor and member of the steroid hormone nuclear receptor family. The ligand binding domain structure has been solved by x-ray crystallography [4]. VDR binding is essential for its genomic activity. These complexes can be both gene and cell specific, enabling the selectivity of $1,25(\mathrm{OH})_{2} \mathrm{D}$ action from cell type to cell type. Vitamin D has potential to inhibit innate immune system. It has been shown to inhibit dendritic cells ability to produce immunity by down-regulating the expression of Major Histocompatibility Complex class II molecules [5]. Dendritic cells have both protective immunity action and self-tolerance. Vitamin D enhances IL-10 production in these dendritic cells and suppresses interleukin (IL)-12 [6]. It also has a complex role in immune hemostatsis with its stimulatory effect on the immune system [5].

Vitamin D also influences the regulation of cathelicidin, which has a broad antimicrobial activity against gram-positive and gram-negative bacteria and produced by humans [7]. Studies show, treatment with Vitamin D up-regulated cathelicidin mRNA in several cell lines and primary cultures including keratinocytes, neutrophils, and macrophages [8].

The CD4 + T-cells activation results in a five-fold increase in VDR expression, enabling vitamin D to regulate number of genes [9]. T-lymphocyte subpopulations demonstrates that induction of Th1 cytokines, especially IFN $\gamma$ is blocked by vitamin D although through the enhancement of production of IL-4 $[10,11]$. Vitamin D overall decreases cell-mediated immune responses. This is due to the effect of vitamin D3 on Antigen Presenting Cells (APC). Apart from the induction and enhancement of suppressive activity of CD $4+$ CD25 + $\mathrm{T}_{\text {reg }}$ cells, it also helps to promote their recruitment at inflammatory sites.

The key role of vitamin D is to maintain proper extracellular calcium levels. Hence vitamin D is essential in maintaining skeletal integrity. It helps to modulate skeletal and mineral homeostasis. The relative ratio of RANKL to OPG determines the formation of mature osteoclast formation therby bone resorption. Most of the studies show that vitamin D-VDR stimulates RANKL expression in cells such as osteoblasts and bone marrow-derived stromal cells [12] as RANKL gene structure contains vitamin D responsive elements.

However, Kitazaw et al. [12] reported that long-term exposure to vitamin D led to a recovery of OPG expression while vitamin D initially represses OPG. Indeed, vitamin D has several anabolic effects on osteoblasts, including stimulation of osteopontin and alkaline phosphatase indicating the necessity of vitamin D to stimulate bone remodeling and formation of new bone.

Recent studies showed significant associations between dierary intake of calcium and improvement of periodontal health [13]. In a recently published longitudinal study, Garcia et al. [13] reported that calcium and vitamin D supplementation may reduce the severity of periodontal disease if used at doses higher than 800-1,000 IU daily. In addition to its role in calcium and bone metabolism, it acts as an anti-inflammatory agent that has strong antibiotic effect. This suggests that vitamin D can negatively affect periodontopathogens thereby helpful in the treatment of periodontitis.

Several diseases including periodontal disease have been reported the associations of many VDR restriction fragment length polymorphism (RFLPs) [14]. Further studies are required to elucidate the functional relevance of VDR RFLPs and disease pathogenesis. An inverse association between the serum 25-hydroxyvitamin D3 concentrations and periodontal disease has been reported [15]. The above findings indicate that $1,25(\mathrm{OH})_{2} \mathrm{D}_{3}$ plays a major role in prevention of periodontal disease and reduced levels of $1,25(\mathrm{OH})_{2} \mathrm{D}_{3}$ may be associated with the periodontal disease.

\section{Conclusion}

It is of great interest in identifying means to target specific cells with analogs for the treatment of periodontal disease. But for many of the potential applications clinical trials are lacking despite promising epidemiologic data and animal studies.

The $1,25(\mathrm{OH})_{2} \mathrm{D}_{3}-\mathrm{VDR}$ complex system plays a significant role in maintaining oral health and its dysfunction leads to periodontal disease. Hence, research in vitamin D could make important contributions to the understanding of periodontal diseases and may be beneficial in the treatment due to its direct effect on bone metabolism and its anti-inflammatory properties.

\section{References}

1. Holick MF (2007) Vitamin D deficiency. N Engl J Med 357: 266-281.

2. Zittermann A (2006) Vitamin D and disease prevention with special reference to cardiovascular disease. Prog Biophys Mol Biol 92(1): 3948.

3. Lips P (2006) Vitamin D Physiology. Prog Biophys Mol Biol 92(1): 4-8.

4. Rochel N, Wurtz JM, Mitschler A, Klaholz B, Moras D (2000) The crystal structure of the nuclear receptor for vitamin $\mathrm{D}$ bound to its natural ligand. Mol Cell 5(1): 173-179.

5. Mora JR, Iwata M, von Andrian UH (2008) Vitamin effects on the immune system: Vitamins A and D take centre stage. Nat Rev Immunol 8(9):685-698.

6. Kamen DL, Tangpricha V (2010) Vitamin D and molecular actions on the immune system: Modulation of innate and autoimmunity. J Mol Med (Berl) 88(5): 441-450.

7. Dimeloe S, Nanzer A, Ryanna K, Hawrylowicz C (2010) Regulatory T cells, inflammation and the allergic response-The role of glucocorticoids and Vitamin D. J Steroid Biochem Mol Biol 120(2-3): 86-95.

8. Wang TT, Nestel FP, Bourdeau V, Nagai Y, Wang Q et al. (2004) Cutting edge: 1, 25-dihydroxyvitamin D3 is a direct inducer of antimicrobial peptide gene expression. J Immunol 173(5): 2909-2912.

9. Shevde NK, Plum LA, Clagett Dame M, Yamamoto H, Pike JW, et al. (2002) A potent analog of 1alpha, 25-dihydroxyvitamin D3 selectively induces bone formation. Proc Natl Acad Sci U S A 99(21): 13487-13491. 
10. Holtrop ME, Cox KA, Clark MB, Holick MF, Anast CS (1981) 1, 25-dihydroxycholecalciferol stimulates osteoclasts in rat bones in the absence of parathyroid hormone. Endocrinology 108(6): 2293-2301.

11. Wei S, Tanaka H, Kubo T, Ono T, Kanzaki S, et al. (1997) Growth hormone increases serum 1, 25-dihydroxyvitamin D levels and decreases 24,25-dihydroxyvitamin D levels in children with growth hormone deficiency. Eur J Endocrinol 136(1): 45-51.

12. Lacey DL, Timms E, Tan HL, Kelley MJ, Dunstan CR, et al. (1998) Osteoprotegerin ligand is a cytokine that regulates osteoclast differentiation and activation. Cell 93(2): 165-676.
13. Andresen C, Olson E, Nduaka C, Pero R, Bagi CM (2006) Action of calciotropic hormones on bone metabolism - Role of Vitamin D3 in bone remodeling events. Am J Immunol 2(2): 40-51.

14. Holick MF (2004) Vitamin D: Importance in the prevention of cancers, type 1 diabetes, heart disease, and osteoporosis. Am J Clin Nutr 79(3): 362-371.

15. Heaney RP, Davies KM, Chen TC, Holick MF, Barger Lux MJ (2003) Human serum 25-hydroxycholecalciferol response to extended oral dosing with cholecalciferol. Am J Clin Nutr 77(1): 204-210.

\section{Your next submission with Juniper Publishers will reach you the below assets}

- Quality Editorial service

- Swift Peer Review

- Reprints availability

- E-prints Service

- Manuscript Podcast for convenient understanding

- Global attainment for your research

- Manuscript accessibility in different formats

( Pdf, E-pub, Full Text, Audio)

- Unceasing customer service

Track the below URL for one-step submission https://juniperpublishers.com/online-submission.php 